\title{
VARIATION OF DENSITY, SPECIES COMPOSITION AND DOMINANCE OF ROTIFERS AT A SHALLOW TROPICAL RESERVOIR (BROA RESERVOIR, SP, BRAZIL) IN A SHORT SCALE TIME
}

\author{
RODRÍGUEZ, M. P. ${ }^{1}$ and MATSUMURA-TUNDISI, T. ${ }^{2}$ \\ ${ }^{1}$ Escola de Engenharia de São Carlos, Universidade de São Paulo, São Carlos, SP, Brazil \\ ${ }^{2}$ Instituto Internacional de Ecologia, Rua Bento Carlos, 750, CEP 13560-660, São Carlos, SP, Brazil \\ Correspondence to: Takako Matsumura-Tundisi, Instituto Internacional de Ecologia, Rua Bento Carlos, 750, \\ CEP 13560-660, São Carlos, SP, Brazil, e-mail: tundisi@zaz.com.br \\ Received June 8, 1999 - Accepted October 2, 1999 - Distributed February 28, 2000
}

(With 6 figures)

\begin{abstract}
Rotifers are the predominant group of zooplankton found in the majority of reservoirs, constituting more than $60 \%$ of the total zooplankton present. Being opportunistic organisms, they easily adapt to changes in environmental conditions, and it is therefore difficult to establish a constant level of composition and occurrence of a species in specific areas at specific times. In order to establish how changes in composition and predominance of a species occurs within a dynamic system, the daily variation in the total density of rotifers and that of the dominant species were studied at short intervals during a period of 20 days at Lobo (Broa) reservoir. Filinia pejleri and Keratella americana were the predominant species, making up $64.3 \%$ of the total rotifers. However, during the first five days of the study, there was a predominance of two genera, Conochilus (C. coenobasis and C. unicornis) and Keratella (K. americana and K. cochlearis), with the genus Conochilus being substituted by the genus Filinia from the seventh day onwards, which, together with the genus Keratella, was predominant until the end of the study period. The increase in density of Filinia pejleri and Keratella americana was found to be associated with increased wind speed. The resulting turbulence could cause changes in the behavior and metabolism of the organisms, increasing the rate of reproduction, which in turn could be attributed to the greater availability of food through the suspension of material from the lake bed.
\end{abstract}

Key words: Density, composition, dominance, rotifers, reservoir.

\section{RESUMO}

\section{Variação da densidade, composição de espécies e dominância de Rotifera em um reservatório tropical raso (reservatório do Broa, SP, Brasil) em uma curta escala de tempo}

Os Rotifera constituem o grupo dominante de zooplâncton da maioria das represas, representando mais de $60 \%$ do total da comunidade zooplanctônica. Por serem organismos oportunistas, adaptamse com facilidade às mudanças das condições ambientais e, assim, dificilmente se encontra um padrão constante de composição e ocorrência de espécies no espaço e no tempo. Com o objetivo de verificar como as mudanças na composição e na dominância das espécies ocorrem em um sistema dinâmico, no caso Represa do Broa, em curtos intervalos de tempo, foi feito o estudo da variação diária da densidade total de Rotifera e das populações dominantes, no período de 20 dias. Filinia pejleri e Keratella americana foram as espécies dominantes, perfazendo $64,3 \%$ do total de Rotifera. Entretanto, em termos diários foi verificado que, nos primeiros cinco dias de estudo, houve a dominância da 
associação dos gêneros Conochilus (C. coenobasis e C. unicornis) e Keratella (K. americana e $K$. cochlearis), sendo que no $7^{\mathrm{o}}$ dia o gênero Conochilus foi substituído pelo gênero Filinia, que em associação com o gênero Keratella predominou até o final do período de estudo. Essa mudança na dominância se encontra associada também ao aumento da densidade dos organismos, que por sua vez coincide com o aumento da velocidade do vento ocorrido no dia anterior a esses eventos. $\mathrm{O}$ vento pode provocar mudança no comportamento e no metabolismo dos organismos por meio da turbulência, aumentando a taxa reprodutiva que, por sua vez, pode estar associada à maior disponibilidade de alimento através da ressuspensão do material do fundo.

Palavras-chave: Densidade, composição, dominância, Rotifera, reservatório.

\section{INTRODUCTION}

Rotifers are considered opportunistic organisms found in high density in the most reservoirs outnumbering the other groups of zooplankton. Several species present a large capacity to fit at the environmental changes adjusting each of them at the particular conditions. Therefore the dominance of species and the fluctuation of rotifer population density in the reservoir of tropical region are very irregular not showing any regular pattern of seasonality or succession of species as has been observed in the temperate ones. Also the species composition in the reservoirs is not constant as has been observed at the other lakes with more stable conditions.

Despite several studies in zooplankton community including rotifers have been carried out at the Lobo (Broa) reservoir by MatsumuraTundisi (1976), Neumann-Leitão et al. (1990) e Oliveira-Neto (1993) few papers have been focused at the cause of variation of the composition and abundance of rotifers in this reservoir.

To attend this question it was proposed to investigate the variation of species composition, dominance of species at a short time scale, with daily samplings and correlating with some environmental factors such as precipitation, wind force and physical and chemical variables.

\section{MATERIAL AND METHODS}

Samplings were carried out at the fixed station of Lobo (Broa) reservoir, near the dam, at the deepest region with $10 \mathrm{~m}$ depth, during the period of August, 25 to September, 13, 1995. This reservoir has been investigated since 1971, in several ecological aspects in order to understand the operation of the hydrodynamic chemical and biological processes of this shallow and artificial lake. The morphometry and the general characteristics of the reservoir are described in Tundisi et al. (1972a,b).

Zooplankton samples were obtained using net plankton with $40 \mathrm{~mm}$ mesh size through the vertical hauls lowering the net twice to the bottom obtaining approximately $1.3 \mathrm{~m}^{3}$ of filtered water. The concentrated material was fixed with $4 \%$ formaldehyde.

Hydrographical data such as water temperature, dissolved oxygen, $\mathrm{pH}$, conductivity were obtained in situ at each 0.5 meters using Horiba sensor measurements. For nutrients analysis such as total carbon, nitrogen and phosphorous water samples were obtained from the surface, $50 \%$ of light penetration $(2.0-2.7 \mathrm{~m})$, at the limit of euphotic zone (4.0-5.4 m) and from the bottom. Different forms of nitrogen such as ammonium, nitrate and nitrite were analyzed.

Chlorophyll $a$ and phaeophytin were also determined using the technique described in Nush (1980) and were sampled at the same depths carried out for nutrients.

Rotifers were identified at level of species and its densities were determined by the counting of organisms in a Sedgewick Rafter cell in the microscope taking subsamples of $1 \mathrm{ml}$. The densities were expressed in number of organisms $\mathrm{m}^{-3}$.

\section{RESULTS}

\section{Precipitation and wind velocity}

The main climatological factors such as precipitation and wind velocity that can affect he distribution of plankton were measured and are presented in the Fig. 1. The region is normally characterized in winter (July to September) by a 
dry period and high wind velocity that act at the main axis (northern direction) of the reservoir. As can be seen in the figure at the period of study 25/
08/95 to $13 / 09 / 95$, no precipitation was measured and sometimes wind velocity of $17.27 \mathrm{~km} \mathrm{~h}^{-1}$ was obtained.

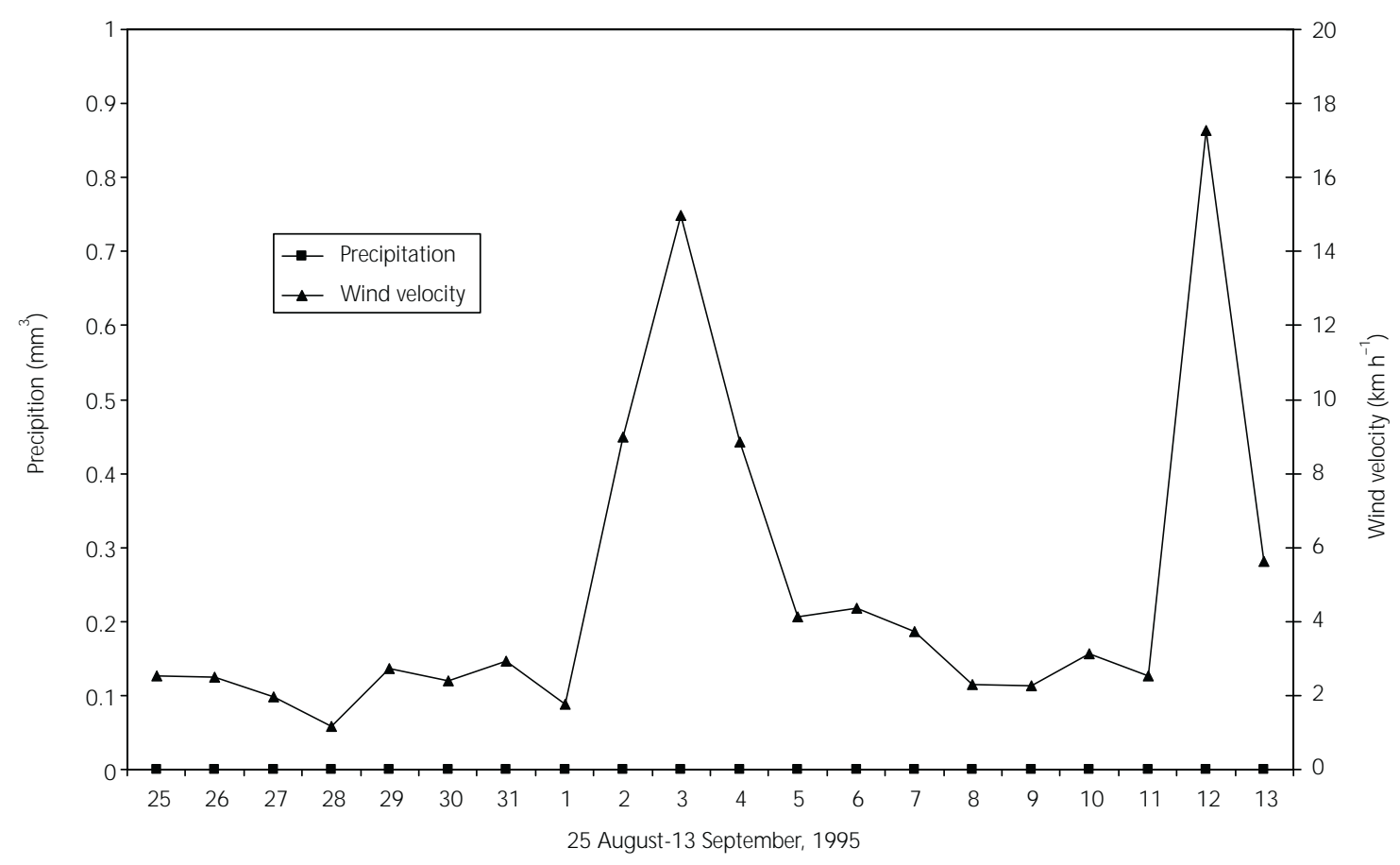

Fig. 1 - Daily variation of precipitation and wind velocity at the Broa reservoir during the period of study.

\section{Water temperature}

The daily variation of the temperature at the surface and depth $(10 \mathrm{~m})$ of the reservoir is shown in the Fig. 2. At the surface the temperature fluctuated from the minimum of $20.6^{\circ} \mathrm{C}$ to a maximum of $22.8^{\circ} \mathrm{C}$ and at the depth from $20.0^{\circ} \mathrm{C}$ to $21.4^{\circ} \mathrm{C}$.

An increasing of surface temperature was observed at the first 10 days of sampling establishing a weak thermal stratification.

\section{Dissolved oxygen}

Fig. 3 shows the daily variation of dissolved oxygen registered at the surface and at the deep layers of Lobo (Broa) reservoir during the 20 days of continuous sampling. The reservoir normally is well oxygenated from surface to bottom but during the period of thermal stratification a depletion of dissolved oxygen was observed. The minimum and maximum values registered at the surface layer were respectively $7.81 \mathrm{mg} \mathrm{l}^{-1}$ and 9.46 $\mathrm{mg} \mathrm{l}^{-1}$ and at the bottom they were: $2.48 \mathrm{mg} \mathrm{l}^{-1}$ and $8.29 \mathrm{mg} \mathrm{l}^{-1}$.

\section{$p H$, conductivity and nutrients(nitrogen and phosphorus)}

Table 1 shows the values of $\mathrm{pH}$, conductivity and nutrients concentration (nitrogen and phosphorus) in the period of study at Broa reservoir. The water presents slightly acid (range of $\mathrm{pH} 5.3$ to 7.4), low conductivity (5-8.0 $\mu \mathrm{S} \mathrm{cm} \mathrm{cm}^{-1}$ ) and low concentration of nutrients both nitrogen and phosphorus. The nitrate varied from 3.8 to $8.5 \mu \mathrm{g}$ $1^{-1}$ and ammonium 11.7 to $37.6 \mu \mathrm{g}^{-1}$. The mean value of total nitrogen was $410.0 \mu \mathrm{g} \mathrm{l}^{-1}$. Total phosphorus showed a range of $12.3 \mu \mathrm{g}^{-1}$ to 40.5 $\mu \mathrm{g}^{-1}$ while the range of orthophosphate was 6.5 to $7.9 \mu \mathrm{g} \mathrm{l}^{-1}$. 


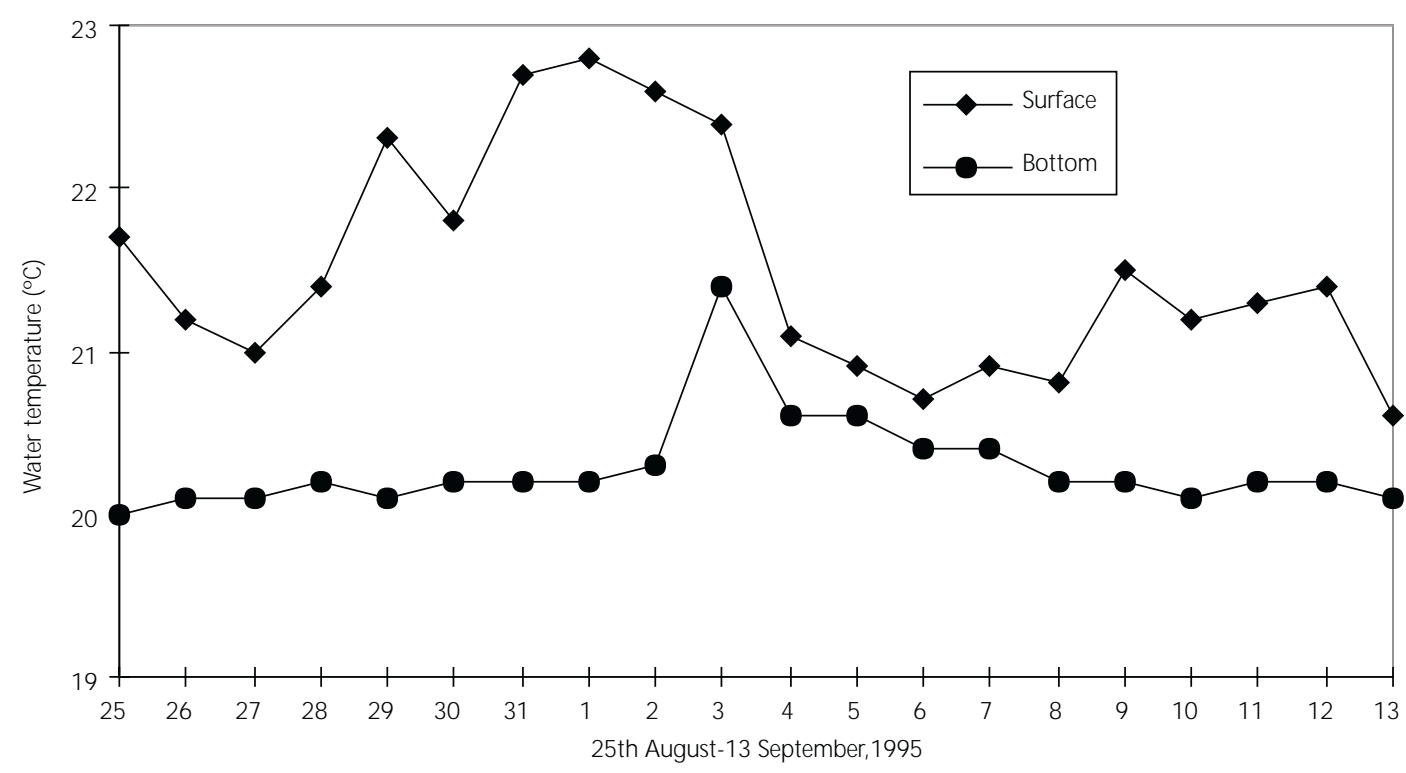

Fig. 2 - Daily variation of water temperature at the surface and bottom of Broa reservoir during the period of study.

TABLE 1

Maximum, minimum and mean values of $\mathrm{pH}$ conductivity and nutrient concentration, at Broa reservoir during $25 / 08$ to $13 / 09 / 1995$.

\begin{tabular}{|l|c|c|c|}
\hline & Mean value & Maximum value & Minimum value \\
\hline $\mathbf{p H}$ & 6.15 & 7.40 & 5.30 \\
\hline Conductivity $\quad\left(\mu \mathrm{S} \mathrm{cm}^{-1}\right)$ & 6.50 & 8.00 & 5.00 \\
\hline Total organic nitrogen $\left(\mathrm{mg} \mathrm{l}^{-1}\right)$ & 410.00 & 560.00 & 290.00 \\
\hline Nitrate $\left(\mu \mathrm{g} \mathrm{I}^{-1}\right)$ & 6.50 & 8.50 & 3.80 \\
\hline Ammonium $\left(\mu \mathrm{g} \mathrm{I}^{-1}\right)$ & 23.10 & 37.60 & 11.70 \\
\hline Total phosphorus $\left(\mu \mathrm{g} \mathrm{I}^{-1}\right)$ & 24.10 & 40.50 & 12.30 \\
\hline Orthophosphate $\left(\mu \mathrm{g} \mathrm{I}^{-1}\right)$ & 7.00 & 7.90 & 6.50 \\
\hline
\end{tabular}

Species composition, dominance and density variation of Rotifera populations

During the period of study the rotifer group from limnetic region showed a poor richness of species composed by 14 species (Table 2 ) and dominated by two species: Filinia pejleri contributing with $36.4 \%$ of the total Rotifera and Keratella americana with $27.9 \%$. The daily variation of the populations Filinia pejleri $36.4 \%$ Keratella americana $(27,9 \%)$ and the population of Conochilus unicornis (9.8\%) is shown in the Fig. 4. It can be seen that the rotifers density increase progressively during the period of twenty days of study. This fact is related with the increasing of pheopigments (Fig. 5 ), wind velocity, and better condition of the environment in relation to dissolved oxygen. 


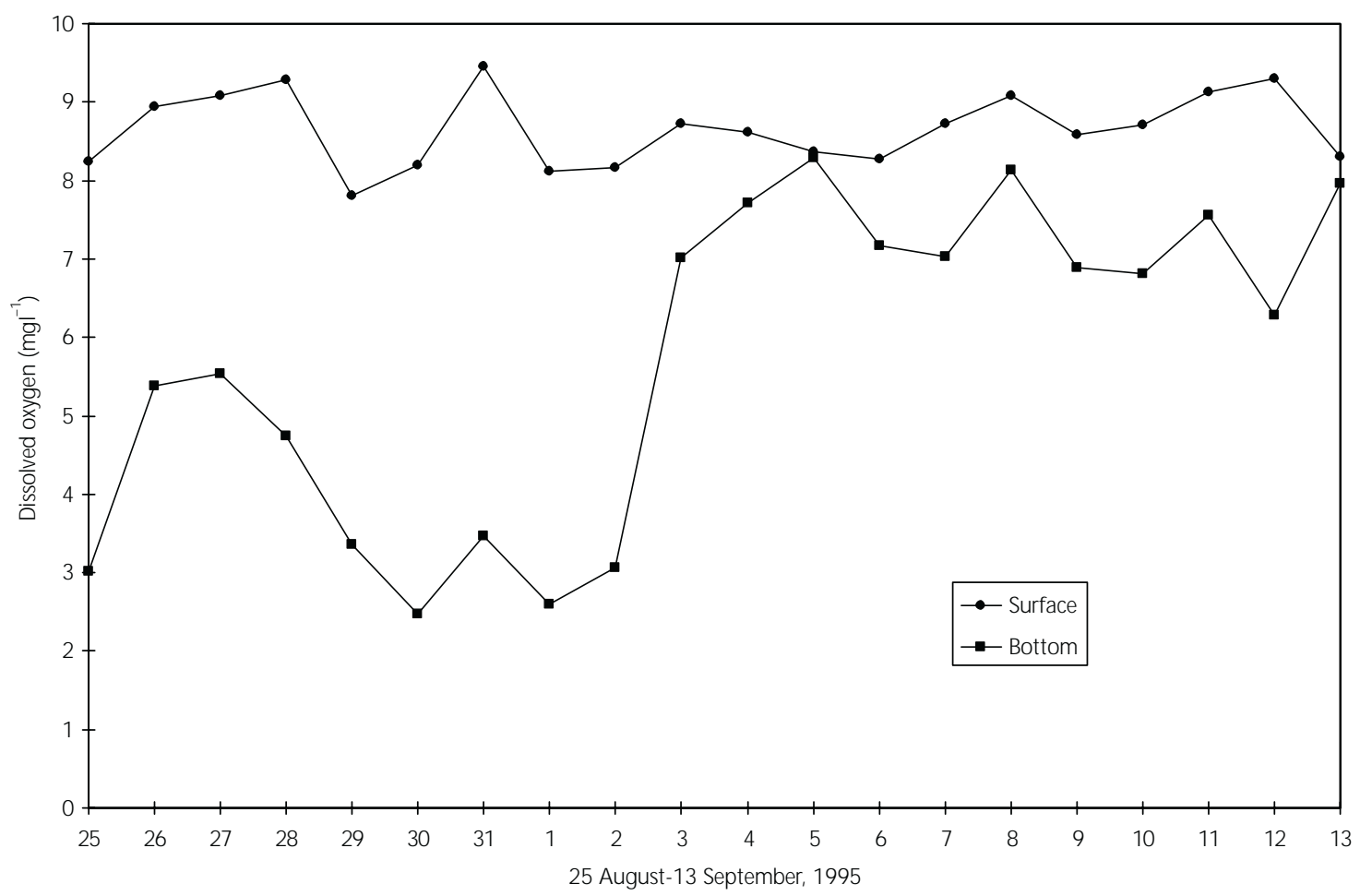

Fig. 3 - Daily variation of dissolved oxygen at the surface and bottom of Broa reservoir.

TABLE 2

Composition and relative abundance (\%) of Rotifera, at Broa reservoir during the period of 25/08 to 13/09/95.

\begin{tabular}{|c|c|}
\hline Species & $\begin{array}{c}\text { Relative abundance } \\
\text { (\%) }\end{array}$ \\
\hline Brachionus mirus & 1.4 \\
\hline Collotheca ornata & 1.8 \\
\hline Conochilus coenobasis & 3.7 \\
\hline Conochilus unicornis & 9.3 \\
\hline Filinia pejleri & 36.4 \\
\hline Hexarthra longicornicula & 5.2 \\
\hline Keratella americana & 27.9 \\
\hline Keratella cochlearis & 3.6 \\
\hline Lecane lunaris & $<1.0$ \\
\hline Lecane signifera & $<1.0$ \\
\hline Macrochaetus collinsi & $<1.0$ \\
\hline Polyarthra vulgaris & 2.0 \\
\hline Ptygura libera & 8.0 \\
\hline Trichocerca similis & $<1.0$ \\
\hline
\end{tabular}




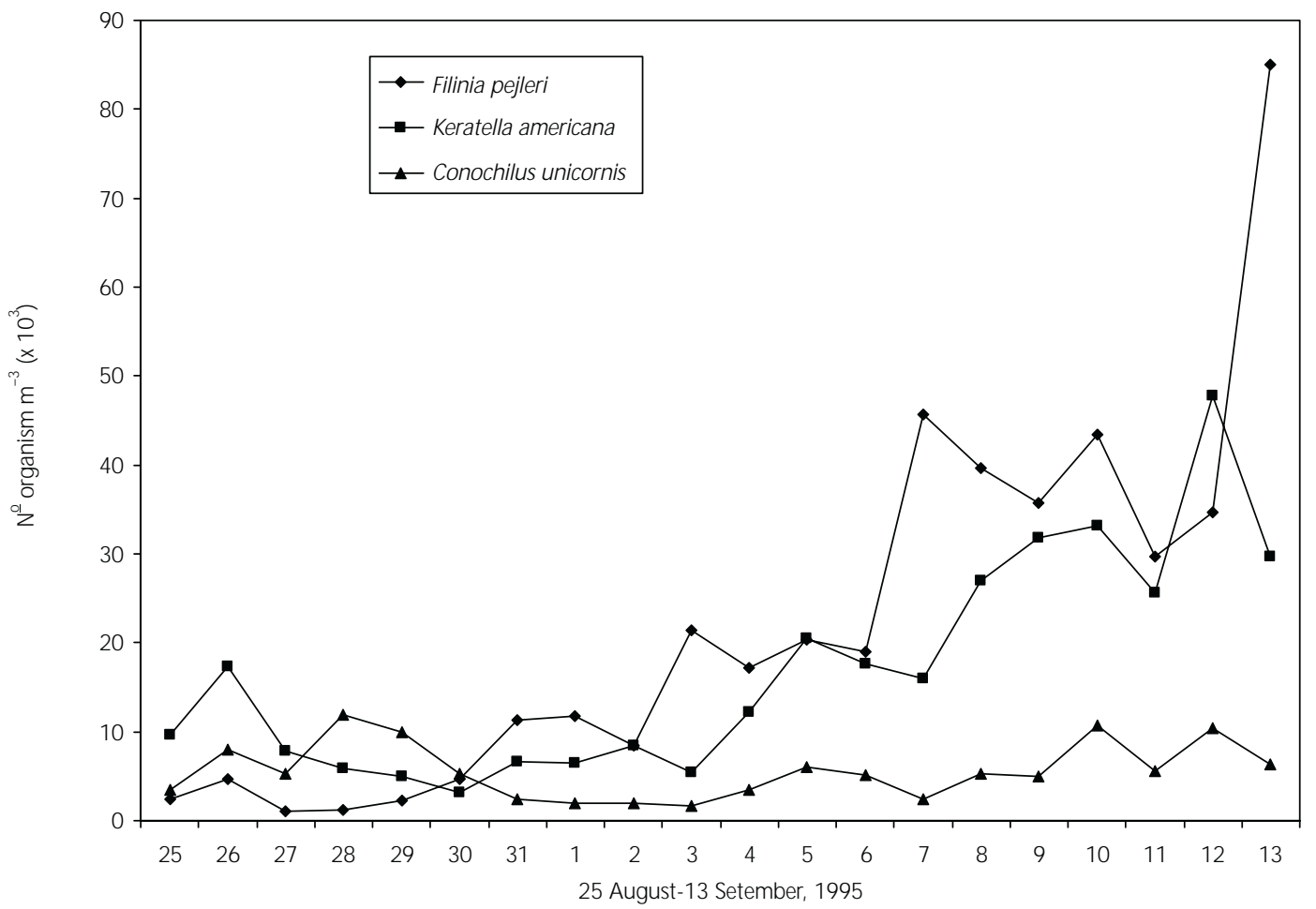

Fig. 4 - The daily variation of the populations Filinia pejleri, Keratella americana and Conochilus unicornis.

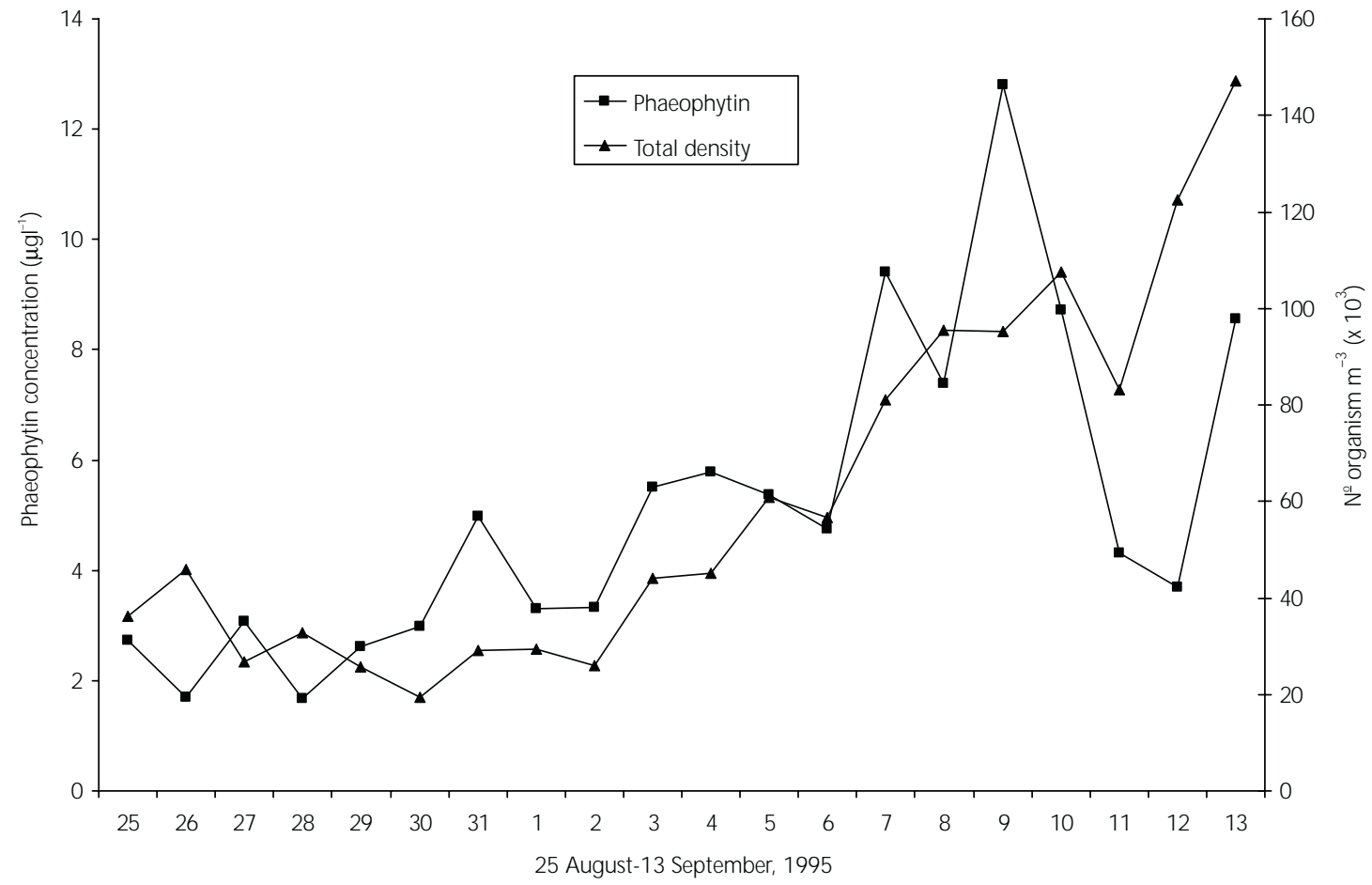

Fig. 5 - The relationship between phaeophytin and abundance of total rotifers at the Broa reservoir during the period of study. 


\section{DISCUSSION}

The Rotifera populations of most reservoirs present a strong variation in its density, species composition and in the dominant assemblage of species in a very short scale time. Broa reservoir a small artificial shallow lake studied since 1971 [Tundisi et al. (1972a, b)] is a reasonable preserved environment from the human activities presenting low concentration of nutrients and chlorophyll $a$, and a well oxygenated water column.

The species composition of rotifers registered by Matsumura-Tundisi (1976) remains with the same composition almost 30 years later, showing sometimes the dominance of assemblage of Ptygura libera, Filinia (longiseta + limnetica), Conochilus (unicornis + coenobasis), Keratella cochlearis (Matsumura-Tundisi, 1976) or the other assemblage of species. Oliveira-Neto (1993) found during the winter the dominance of assemblage of Ptygura libera, Keratella cochlearis and Polyarthra vulgaris as well as of the Collotheca campanulata and Keratella americana. Nevertheless during the summer the assemblage of Keratella. americana, Hexarthra mira and Ptygura libera or Keratella cohlearis and Ptygura libe$r a$ were observed. Silva (1994) has found Filinia limnetica, Brachionus falcatus and Ptygura libera dominating the Rotifera population and the present data showed the assemblage of Filinia pejleri and Keratella americana composing $64 \%$ of the total Rotifera.

It is not possible to observe in the reservoirs of tropical regions any pattern of succession of species of rotifers being their occurrence unexpected and growing up large transitory populations. Several factors are responsible for that behavior such as the intrinsic characteristic of the group to adapt rapidly to the more adverse conditions caused by climate conditions or by environmental physical, chemical and biological interactions.

According to Odum (1983) in the tropical region the seasonal rhythm of precipitation is very important to the reproductive activity of the organisms and it corresponds to those temperate regions where the rhythm of light and temperature regulate the reproduction of organisms.

In the present data obtained only during the drought period for 20 days, the species populations did not show a sharp variation in its dominance.
At the first five days the Rotifera was dominated by Conochilus (coenobasis + unicornis) and Keratella americana. However on the $7^{\text {th }}$ day the Conochilus was replaced by Filinia pejleri that associated with $K$. americana dominated the rotifer population of the remaining period increasing also in its abundance.

This enhancement is associated with the increase in wind velocity. In Broa reservoir it was verified that a wind speed of $10 \mathrm{~km} \mathrm{~h}^{-1}$ is able to resuspended the material from the bottom (Tundisi $\&$ Matsumura-Tundisi, 1995). Therefore through turbulence increasing food disponibility to detritus filter feeders and stimulating also their reproductive rate. As has been observed by Ruttner-Kolisko (1980) with Filinia terminalis a microfiltrator (particles less than $10 \mathrm{~mm}$ ) feeding on nannoplankton, bacteria and plankton in decomposition, Filinia pejleri has probably the similar behavior. The enhancing of F. pejleri density showed a good correlation $(\mathrm{r}=0.74)$ with phaeopigments concentration (Fig. 6). Keratella americana was better correlated with chlorophylla.

Hofmann \& Hofle (1993), in the case of Keratella and Conochilus populations, verified that the growth of Keratella (cochlearis + quadrata) was directly related with nutrients and chloropyll concentration and inversely related in the case of Conochilus unicornis. During the occurrence of thermal stratification in this reservoir even for a short period, Oliveira- Neto (1993), observed a segregation in the distribution of dominant species in the various layers of water column. Ptygura libera was most abundant at the epilimnion, Keratella cochlearis in the metalimnion and Hexarthra mira in the hypolimnion. Some species belonging to the genera Hexarthra and Filinia are tolerant to low concentration of oxygen dwelling in the hypoxic layer of the lakes.

The biological diversity of limnetic rotifers of Broa reservoir is not so high (16 to 20) and the pulse of dominant species (usually represented by the association of two or three species) that occurs from time to time does not last for more than one month and they are substituted for other association of species. Frequently we can observe in this reservoir the explosion of populations of Ptygura libera, Keratella cochlearis, Keratella americana, Polyarthra vulgaris, Filinia terminalis, Filinia limnetica, Filinia pejleri, Conochilus unicornis and Hexarthra mira. 


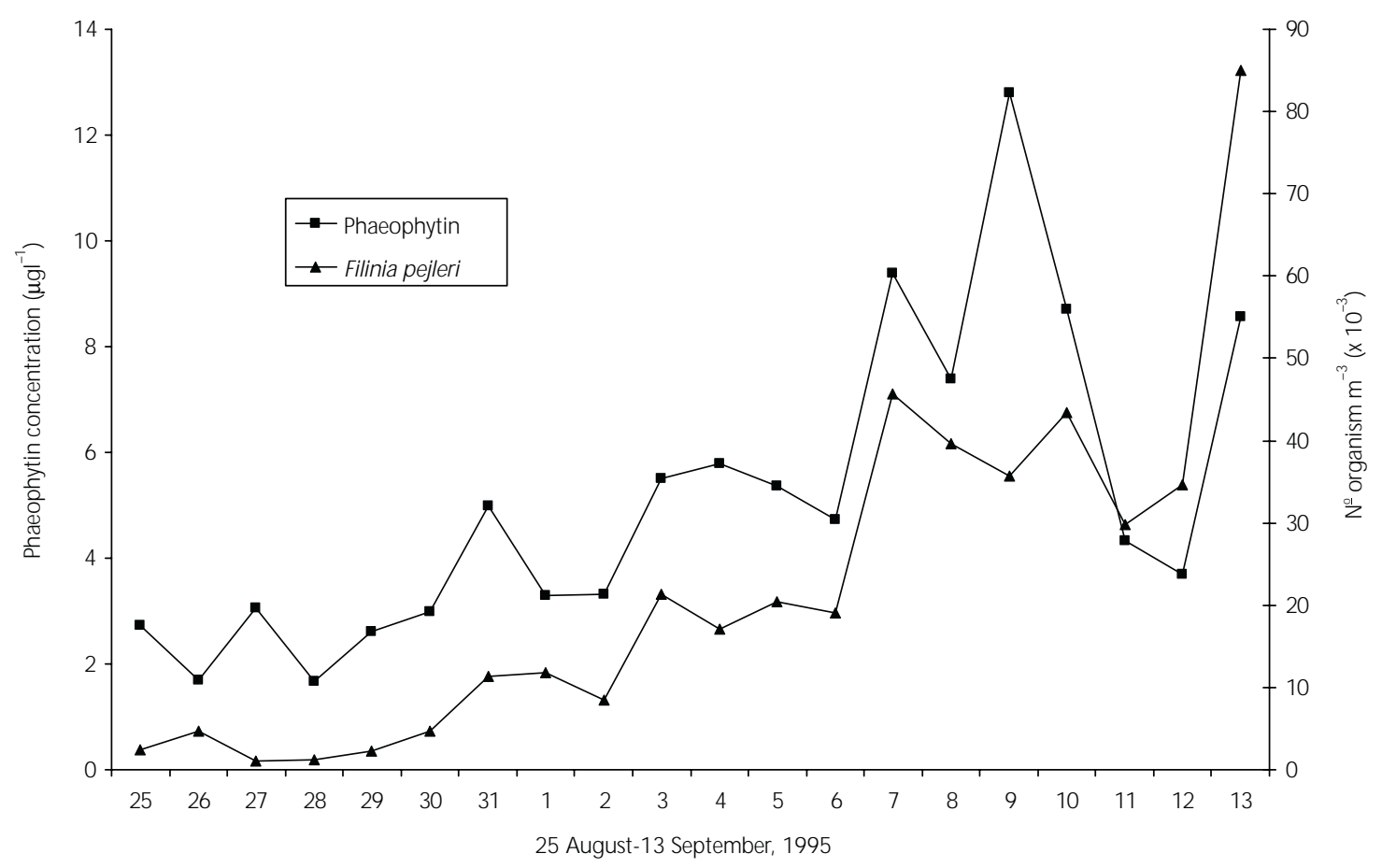

Fig. 6 - Daily distribution of Filinia pejleri population density and the concentration of phaeophytinat at the Broa reservoir during the period of study.

However the littoral zone shows a richness of species as has been detected by Segers et al. (1995), where it was found +102 species, showing that this region is more favorable for the colonization and niche development of Rotifera.

Acknowledgements - The authors express their thanks to CAPES (Coordenadoria de Aperfeiçoamento de Pessoal de Ensino Superior) and FAPESP (Process: 91/0612-5).

\section{REFERENCES}

HOFMANN, W. \& HOFLE, M. G., 1993, Rotifer population dynamics in response to increased bacterial biomass and nutrients: a mesocosm experiment. Hydrobiologia 255/ 256: $171-175$.

MATSUMURA-TUNDISI, T. \& TUNDISI, J. G., 1976, Plankton studies in a lacustrine environment. I. Preliminary data on zooplankton ecology of Broa Reservoir. Oecologia, 25: 265-270.

NEUMANN-LEITÃO, S., MATSUMURA-TUNDISI, T. \& CALIJURI, M. C., 1990, Distribuição e aspectos ecológicos do zooplancton da Represa do Ribeirão do Lobo (Broa) São Paulo. In: ENCONTRO BRASILEIRO DE PLANCTON, 4., RECIFE, 1990. Anais. Recife, UFPE, 393-413.
NUSCH, E. A., 1980, Comparison of different methods for chlorophyll and phaeopigment determination. Arch. Hydrobiol. Brih. Ergebn. Limnol., 14: 14-36.

ODUM, E. P., 1983, Ecologia. Rio de Janeiro, Guanabara.

OLIVEIRA-NETO, A. L., 1993, Estudo da comunidade zooplânctonica, com ênfase na comunidade de rotíferos, em curtos intervalos de tempo (variações diárias e nictemerais) na Represa do Ribeirão do Lobo (Broa). Itirapina, São Paulo. Dissertação (Mestrado), Instituto de Biociencias, Universidade de São Paulo, 120p.

RUTTNER-KOLISKO, A., 1980, The abundance and distribution of Filinia terminalis in various types of lakes as related to temperature, oxygen, and food. Hydrobiologia, 73: $169-175$

SEGERS, H. \& DUMONT H. J., 1995, 102 + rotifer species (Rotifera: Monogonanta) in Broa reservoir (SP., Brazil) on 26 August 1994, with the description of three new species. Hydrobiologia, 316: 183-197.

SILVA, L. A., 1994, Estudo da composição específica, distribuição vertical e flutuação sazonal da comunidade zooplantônica da Represa do Ribeirão do Lobo (Broa). Monografia (Graduação), Universidade Federal de São Carlos.

TUNDISI, J. G., MATSUMURA-TUNDISI, T., STRIXINO G., MARTINS, M., MATOS, M. A. \& SANTOS, E. P., 1972a, Ecological studies at Broa Reservoir. I. Progress Report. Federal University of São Carlos. Report (1). 
TUNDISI, J. G., MATSUMURA-TUNDISI, T., STRIXINO G., MARTINS, M., MATOS, M. A. \& SANTOS, E. P., 1972b, Ecological studies at Broa Reservoir. II. Progress Report. Federal University of São Carlos. Report (2).

TUNDISI, J. G. \& MATSUMURA-TUNDISI, T., 1995, The Lobo-Broa ecosystem research. In: J. G. Tundisi, C. E. M. Bicudo \& T. Matsumura-Tundisi (eds.) Limnology in Brazil, pp. 219-243. 